\title{
Geographic Information Systems, Remote Sensing, and Spatial Analysis Activities in Texas, 2002-07
}

Geographic information system (GIS) technology has become an important tool for scientific investigation, resource management, and environmental planning. A GIS is a computer-aided system capable of collecting, storing, analyzing, and displaying spatially referenced digital data. GIS technology is particularly useful when analyzing a wide variety of spatial data such as with remote sensing and spatial analysis. Remote sensing involves collecting remotely sensed data, such as satellite imagery, aerial photography, or radar images, and analyzing the data to gather information or investigate trends about the environment or the Earth's surface. Spatial analysis combines remotely sensed, thematic, statistical, quantitative, and geographical data through overlay, modeling, and other analytical techniques to investigate specific research questions. It is the combination of data formats and analysis techniques that has made GIS an essential tool in scientific investigations.

This document presents information about the technical capabilities and project activities of the U.S. Geological Survey (USGS) Texas

Water Science

Center (TWSC)

GIS Workgroup

from 2002

through 2007.

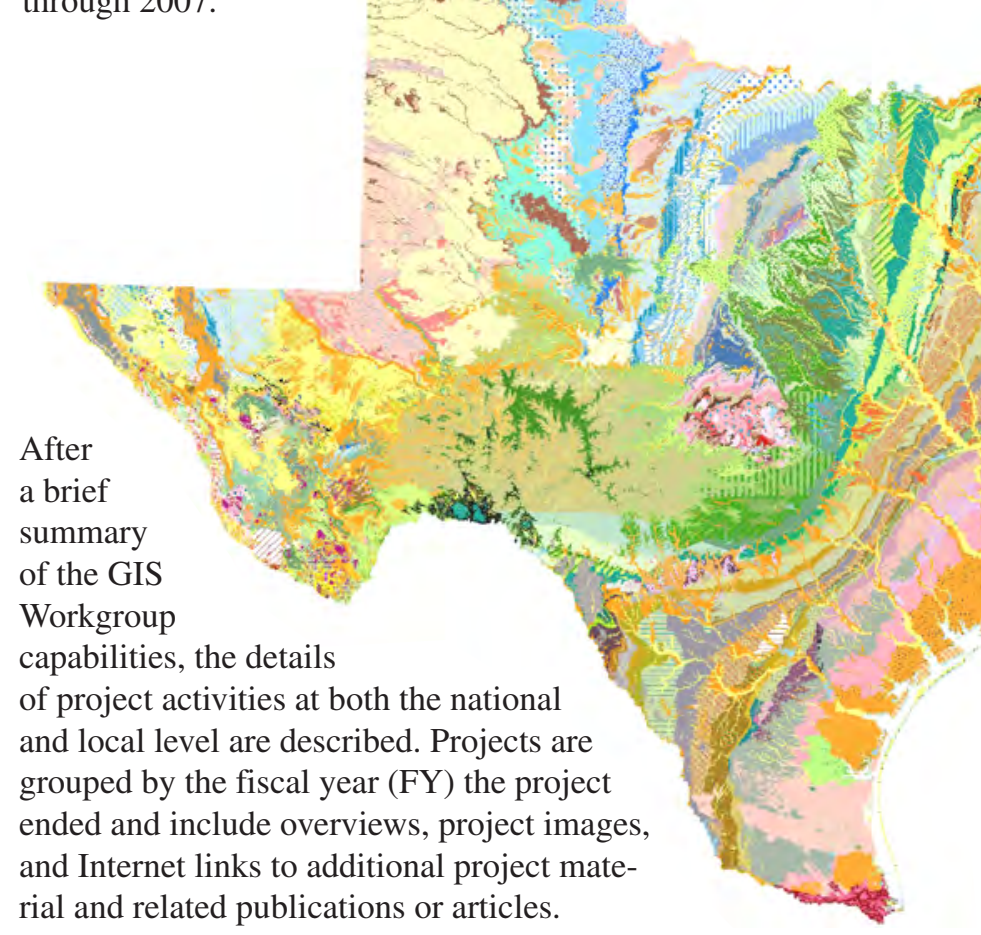

\section{GIS Workgroup}

The USGS Texas GIS Workgroup is comprised of geographers, hydrologists, and geologists in both the Water Resources and Geography disciplines who specialize in GIS, remote sensing, and spatial analysis. We collaborate with resident hydrologists, hydrogeologists, water-quality specialists, limnologists, biologists, geologists, and geographers on a diverse range of projects. There is emphasis on technical training to keep skills current with advances in software and technology. Some of our technical capabilities include

- Spatial data production

- Spatial database administration and management

- Spatial data analysis and modeling

- Spatial data visualization

- Land cover / Land use mapping

- Watershed delineation and characterization

- Programming / Custom tools

The USGS Texas GIS Workgroup actively participates and collaborates with local, State, national, and international members of the GIS community. We regularly contribute to the knowledge base through presentations and publications. Several GIS projects have been presented at conferences such as the Association of American Geographers (AAG) Annual Meeting, Environmental Systems Research Institute, Inc. (ESRI) International Users Conference, Texas GIS Forum, and TWSC Technical Talk Series.

\section{Project Activities}

GIS project activities in the TWSC have steadily increased over the past 6 years. All projects mentioned below, by fiscal year, have a substantial GIS, remote sensing, and/or spatial analysis component. This is not a comprehensive list of projects, but it highlights the skills and capabilities of the GIS Workgroup and shows the increased importance of GIS, remote sensing, and spatial analysis in USGS projects over time. 
Texas Source Water Assessment Project

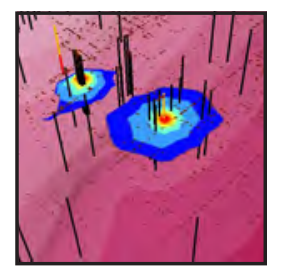

This project was developed in cooperation with the Texas Commission on Environmental Quality (TCEQ) to address the 1996 Amendments to the Safe Drinking Water Act which mandated that each state prepare source water assessment program (SWAP) documentation of all public water supplies (PWS). States were required to determine the drinking-water source, the origin of contaminants monitored and the potential contaminants to be monitored, and the intrinsic susceptibility of the source water. Under the amendments to the act, states created SWAPs to provide an individual source water assessment for each PWS regulated by the State and determined whether an individual drinking water source is susceptible to contamination. The USGS designed and developed database structures, assessment software, and technical documentation specifically designed to support staff in the performance of source water assessments on TCEQ computers.

- 2001 USGS Fact Sheet 101-00: http://pubs.usgs.gov/fs/fs101-00/

\section{FY 2003}

\section{Geodatabase of Texas Springs}

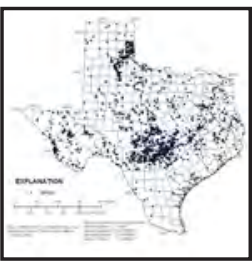

This project was developed in cooperation with the Texas Water Development Board (TWDB) to aggregate and organize site and flow information for springs in Texas using selected digital and hard-copy data sources. Spatial and tabular data were organized into a geodatabase and represent more than 2,000 springs and 7,000 springflow measurements.

- 2003 USGS Open-File Report 03-315: http://pubs.usgs. gov/of/2003/ofr03-315/

\section{Digital Geologic Atlas of Texas}

This project was developed in coop-

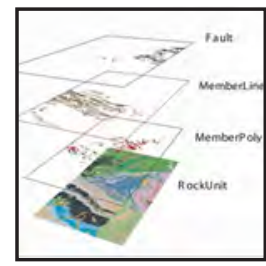
eration with the Texas Water Development Board (TWDB) to produce a library of 38 ESRI personal geodatabases representing the original 38 University of Texas Bureau of Economic Geology map sheets. The digital conversion of the original hardcopy map sheets began October 2002. Project planning among the USGS team estab-

lished the need to use the personal geodatabase format for this procedure. This data format would allow for all the original map data (for example, geologic time, formation descriptions) to be stored in a single database location with the geographic features.

- Project Web site: http://tx.usgs.gov/GAT/
Geodatabase of Water-Level Declines in Springs Associated with Eurycea Salamander Habitats

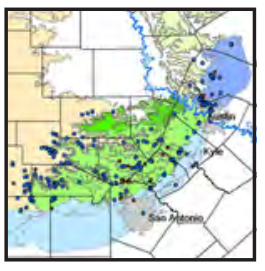

This project was developed in cooperation with the U.S. Fish and Wildlife Service (USFWS) to associate projected waterlevel declines in the middle zone of the Trinity aquifer with Eurycea salamander habitats in springs and caves. Digital elevation models (DEMs) were used to assign elevations to individual spring locations, and a unique querying method was developed to determine the aquifer responsible for each spring, using aquifer geodatasets of the Source Water Assessment Program (SWAP). Projected water-level declines were available from a ground-water availability model (GAM) released by the Texas Water Development Board (TWDB). Spatial and tabular data were organized into a geodatabase.

- 2007 USGS Data Series 243: http://pubs.usgs.gov/ $d s / 2007 / 243 /$

Land-Cover and Imperviousness Data for NAWOA Effects of Urbanization on Stream Ecosystems (EUSE) Project

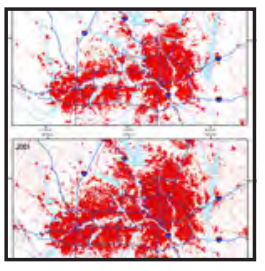

As part of the USGS NAWQA EUSE project, land cover and imperviousness data were produced primarily from Landsat-7 ETM+ satellite imagery for 1999-2002, using methodologies developed by the USGS National Landcover Database 2001 Program. These data are available online and provided as 30-meter-resolution raster datasets. In addition to the land-cover and imperviousness surface derivation, statistics for several hundred GIS-derived datasets were calculated to characterize population, socioeconomic, and infrastructure variables for 29 basins in the DallasFort Worth study area.

- 2006 USGS Data Series 221: http://pubs.usgs.gov/ $d s / 2006 / 221 /$

Geologic Map Compilation of the Upper Seco Creek Area, Medina and Uvalde Counties, South-Central Texas

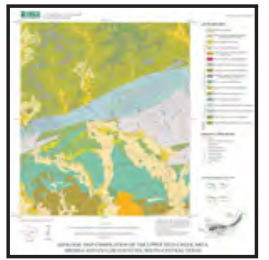

This digital geologic map compilation presents new polygon (map unit contacts) and line (faults) vector data for the Seco Creek area in south-central Texas. The map database, which is at 1:50,000-scale resolution, shows the geology for an area in Medina County about 25 kilometers northwest of San Antonio. The impetus for compiling the geology of the four 7.5-minute-quadrangle (Comanche Waterhole, Flatrock Crossing, Sabinal NE, and Texas Mountain) area was to provide a digital geologic map database for a helicopter electromagnetic (HEM) survey flown 
in 2002 and for ongoing 3-D EarthVision modeling of the boundary between the Edwards aquifer and Trinity aquifer.

- 2004 USGS Open-File Report 2004-1430: http://pubs.usgs. gov/of/2004/1430/

\section{FY 2005}

Geodatabase and 3D Conceptual Model for Air Force Plant 4 and Naval Air Station Carswell Field, Fort Worth, Texas

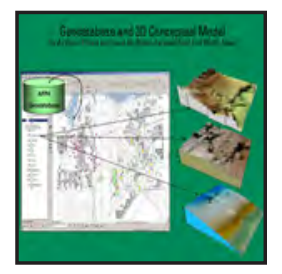

The USGS, in cooperation with the U.S. Air Force, developed a geodatabase and three-dimensional model to improve understanding of the geology, hydrology, and contaminant occurrence at Air Force Plant 4 (AFP4) and adjacent Naval Air Station-Joint Reserve Base Carswell Field (NAS-JRB). Contaminants from the 3,600acre facility, primarily volatile organic compounds (VOCs) and metals, have entered the ground-water-flow system through leakage from waste-disposal sites and from manufacturing processes. Environmental data collected at AFP4 and NAS-JRB during 1993-2002 from several sources in distinct formats created the need for consolidation of the data into a comprehensive temporal and spatial geodatabase that supports a range of hydrologic, geologic and water quality data. A three-dimensional conceptual model of the hydrogeologic units integrally linked to the geodatabase was concurrently designed.

- 2005 USGS Open-File Report 2005-1041: http://pubs.usgs. gov/of/2005/1041/

- 2004 USGS Scientific Investigations Report 2004-5062: http://pubs.usgs.gov/sir/2004/5062/

- 2004 USGS Fact Sheet 2004-3063: http://pubs.usgs.gov/ $f_{s} / 2004 / 3063 /$

\section{Geodatabase of Water Quality for Major Springs in Texas}

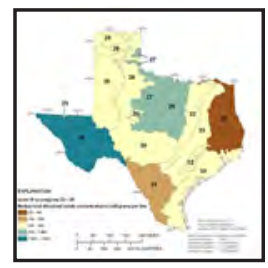

This project was developed in cooperation with the Texas Parks and Wildlife Department (TPWD) to aggregate and organize water-quality information for major springs in Texas using selected digital and hardcopy data sources. Spatial and tabular data were organized into a geodatabase. In addition, water-quality data were spatially assessed for level III ecoregions in Texas.

- 2006 USGS Data Series 230: http://pubs.usgs.gov/ $d s / 2006 / 230 /$

\section{Digital Geologic Atlas of Texas-Statewide Compilation}

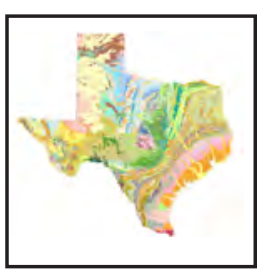

This project was developed in cooperation with the Texas Water Development Board (TWDB) to produce the Statewide Digital Geologic Atlas of Texas (GAT), which would combine the 38 personal geodatabases from Phase I (FY 2003-04) of this project into one ESRI ArcSDE geodatabase containing more than 145,000 geologic features.

- Project Web site: http://tx.usgs.gov/GAT/

Geologic Map of the Edwards Aquifer Recharge Zone, SouthCentral Texas

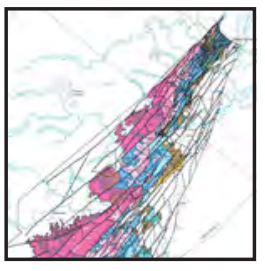

Efforts by a National Cooperative Geologic Mapping Program project to compile the geology of the Edwards aquifer recharge zone in south-central Texas have helped to refine the hydrostratigraphy of one of the most permeable and productive carbonate aquifers in the United States. These data illustrate the detailed geographic extent of the stratigraphic units and faulting for the Edwards aquifer recharge zone in south-central Texas.

- 2005 USGS Scientific Investigations Map 2873: http://pubs. usgs.gov/sim/2005/2873/

\section{FY 2006}

Border Environmental Health Initiative (BEHI): Years 1 \& 2

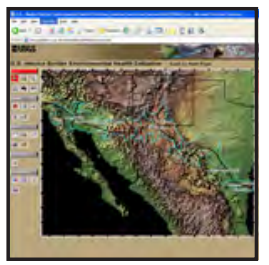

This multidisciplinary USGS project focused on developing an integrated, Webbased, environmental resource database for display and further analysis within a GIS framework. This information system provides the needed data and tools for furthering our understanding of the occurrence and distribution of disease-causing agents in the environment and their specific exposure pathways in water, air, biota, and soil. Efforts concentrated on establishing methodologies for integrating binational base data layers, developing a project Web site with supporting documentation and project information, and creating the border-wide Internet Mapping Service.

- 2004 USGS Fact Sheet 2004-3140: http://pubs.usgs.gov/ $f_{s} / 2004 / 3140 /$

- Project Web site: http://borderhealth.cr.usgs.gov/

- Internet Mapping Service: http://gisdata.usgs.gov/website/ BorderHealth/

\section{USIBWC Internet Map Service}

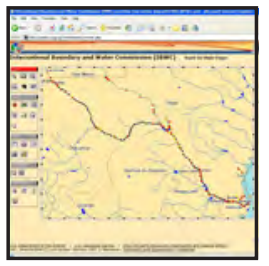

The USGS, in cooperation with the U.S. Section, International Boundary and Water Commission (USIBWC), developed and implemented an interface between the USIBWC GIS and the Water Accounting Division's streamflow-gaging information and the Texas Clean Rivers Program waterquality monitoring program. An interactive map displays the location of streamflow gages and water-quality monitoring sites, providing public access to data collected by both the Texas Clean Rivers Program and the Water Accounting 
Division. The interactive map provides an open-access link to the data and the ability to query the data.

- Internet Mapping Service: http://gisdata.usgs.gov/website/ $i b w c /$

National Land Cover Database (NLCD 2001) - Zone 32

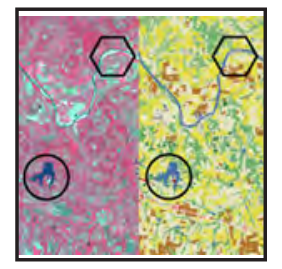

This project was developed in cooperation with the Earth Resources and Observation Science (EROS) Data Center to produce land cover data for mapping zone 32, which covers parts of northern Texas, Kansas, and Oklahoma. The NLCD 2001 was created by partitioning the United States into mapping zones. A total of 66 mapping zones were delineated in the conterminous United States on the basis of ecoregion and geographical characteristics, edge-matching features, and size requirement of Landsat mosaics. Methodology developed at EROS Data Center (http:// landcover.usgs.gov/pdf/asprs_final.pdf) was used for this effort.

- Project Web site: http://www.mrlc.gov/

\section{Panhandle Groundwater Conservation District Geodatabase Development}

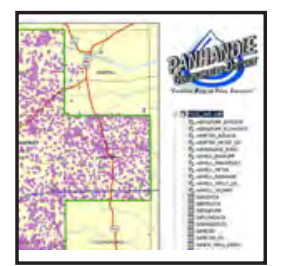

This project was developed in cooperation with the Panhandle Groundwater Conservation District (PGCD) to develop a geodatabase that would allow PGCD to effectively input and manage data to distribute information to their stake holders and the general public. Both spatial and tabular data were presented in one geodatabase for data input and output. A data dictionary containing definitions of coded values was developed for data input.

- Project Web site: http://tx.usgs.gov/PGCD/

\section{Binational Networked Hydrography System for the U.S.-Mexico} Border, Phase 1

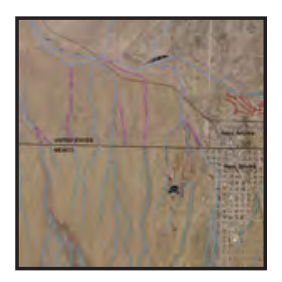

In cooperation with the U.S. International Boundary and Water Commission (USIBWC), the USGS began work on a routable ArcHydro ${ }^{\mathrm{TM}}$ stream network for the U.S.-Mexico border region from the West Coast to the eastern boundary of southern New Mexico and northern Chihuahua. The stream network consists of the 1:24,000 National Hydrography Dataset stream data and the 1:50,000 Instituto Nacional de Estadística, Geografía e Informática (INEGI) stream data. Phase 1 of the project covered southwestern New Mexico-northwestern Chihuahua and southeastern Arizona-northeastern Sonora, and is now complete. The $\mathrm{ArcHydro}^{\mathrm{TM}}$ data model allows data associated with a stream to be related to the entire network of streams in a geodatabase. For instance, water-quality events and data might be related to a stream and then traced upstream and downstream, allowing potential water-quality effects to be traced to a geographic extent.

Geologic Map of the Edwards Aquifer in Northern Medina and Northeastern Uvalde Counties, South-Central Texas

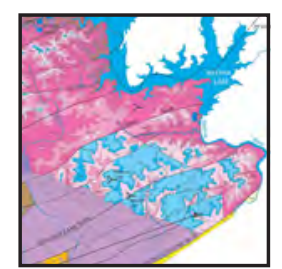

The southern segment of the Edwards aquifer in south-central Texas is one of the most productive subsurface reservoirs of ground water in the world, providing water to more than a million people in the San Antonio region. Dissolution, karst development, and faulting/fracturing directly controls aquifer geometry by compartmental-

izing the aquifer and creating unique ground-water flow paths. The surface geology and fractures were mapped using GIS.

- 2006 USGS Open-File Report 2006-1372: http://pubs.usgs. gov/of/2006/1372/

\section{FY 2007}

Geodatabase and 3D Conceptual Model for the Longhorn Army Ammunition Plant

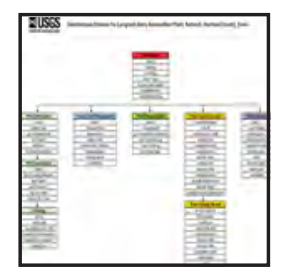

The Longhorn Army Ammunition Plant (LHAAP) relies on historical and current environmental information for environmental management, clean-up, and protection. Currently (2007), various entities conducting work for LHAAP have compiled spatial and non-spatial digital information, including hydrologic, geologic, and water-quality data that can be useful for identifying data gaps and developing a site-wide conceptual model for LHAAP. The USGS, in cooperation with the U.S. Environmental Protection Agency (USEPA), is organizing the large amounts of available data to help effectively manage the data for decision-making, sampling locations, and progress at LHAAP. The spatial and tabular data will be compiled into a single geodatabase with metadata, and a three-dimensional conceptual model will be created to attain a geologic and hydrogeologic perspective of the plant.

- Projected end date: September 1, 2009

\section{Watershed Boundary Dataset}

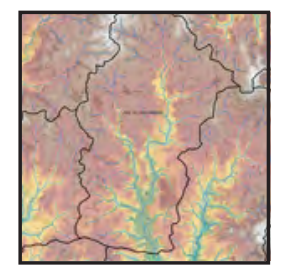

The USGS is collaborating in a multi-agency effort to complete the national Watershed Boundary Dataset (WBD). In Texas, the USGS, in cooperation with Natural Resources Conservation Service (NRCS) Texas, is using federally established standards (ftp://ftp-fc.sc.egov. usda.gov/NCGC/products/watershed/hustandards.pdf) to delineate high-resolution watershed 
boundaries for fifty 8-digit hydrologic units in eastern and coastal Texas.

- Projected end date: October 1, 2007

- Project Web site: http://www.ncgc.nrcs.usda.gov/products/ datasets/watershed/

\section{Border Environmental Health Initiative (BEHI): Years 3 \& 4}

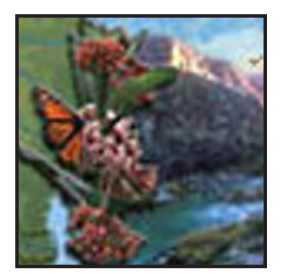

Currently (2007), a multidisciplinary USGS team, in conjunction with the Pan American Health Organization, has begun a 2-year research project to define linkages between environmental and human health. The objective is to use BEHI datasets and analyses of water quality, fish health, geochemistry, and land use to investigate linkages between regional human health issues and environmental health. A GIS-based quantitative weight-of-evidence and logistic regression model to associate areas of poor environmental quality with areas of impaired human health will be used. Additionally, binational datasets are undergoing thorough review and a large number of the datasets will be published and available for download. A download page with links, metadata, and the data in multiple formats is currently (2007) under construction.

- Projected end date: October 1, 2008

- Project Web site: http://borderhealth.cr.usgs.gov/

- Internet Mapping Service: http://gisdata.usgs.gov/website/ BorderHealth/

- 2006 USGS Fact Sheet 2006-3054: http://pubs.usgs.gov/ fs/2006/3054/

Global Map and National Atlas 1:1M Hydrography: Production Phase

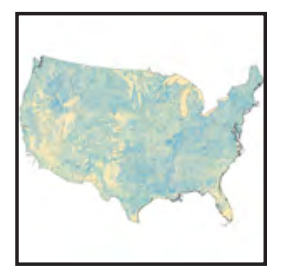

In cooperation with the National Atlas, this project will produce a 1:1,000,000scale $(1: 1 \mathrm{M})$ networked drainage dataset from the existing $1: 100,000$-scale $(1: 100 \mathrm{k})$ National Hydrography Dataset (NHD) for the United States, Puerto Rico, and U.S. Virgin Islands. To accomplish this objective, the USGS developed specialized geoprocessing tools and algorithms using ESRI ArcObjects to partially automate generalization and simplification of the NHD network. The final datasets will be available through the USGS National Atlas in both shapefile and geodatabase formats (http://www.nationalatlas.gov/) and through the Global Mapping Project (http://www.iscgm.org/).

- Projected end date: October 1, 2007
Geologic Atlas of Texas (GAT)—Geodatabase Maintenance

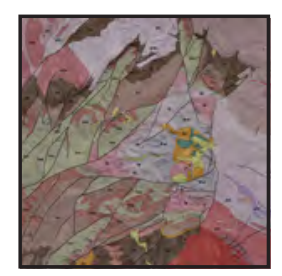

Continuing a cooperative effort that began in FY 2004 with the Texas Water Development Board (TWDB), this project provides updates and revisions to the Digital Geologic Atlas of Texas (GAT) where needed. Using ArcGIS, in concert with ESRI's Production Line Toolset, the UGGS will document and verify all changes to the Digital GAT for archival purposes. The USGS will also prototype the incorporation of high-resolution $(1: 24,000)$ geologic data into the current structure by using digital data recovery methods for the University of Texas, Bureau of Economic Geology, Geologic Quadrangle Map Series. In addition, the USGS will produce educational materials that will instruct end-users about the functionality of the Digital GAT geodatabases.

- Projected end date: October 1, 2007

- Project Web site: http://tx.usgs.gov/GAT/

\section{Source Water Assessment Program Toxic Algae Study}

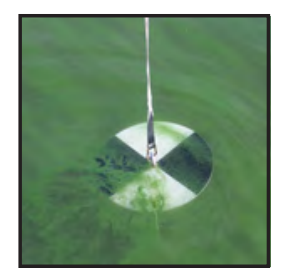

In cooperation with the Texas Commission on Environmental Quality (TCEQ) Source Water Assessment program (SWAP), the USGS plans to investigate the presence of blue-green algal toxins and taste and odor compounds associated with harmful algal blooms (HABs) in drinking water sources. Field data and lab results were loaded into the USGS National Water Information System (NWIS) (http://waterdata.usgs.gov/nwis) and published in the Annual Data Report. Spatial analysis is focusing on linkages between drainage-area characteristics, environmental data, nutrient loads, and presence of HAB compounds of concern (algal toxins and taste and odor compounds). The water-quality data were pulled from NWIS and spatially enabled using the NWIS geodatabase snapshot schema. The schema effectively translates NWIS codes, establishes relationships, and formats data to allow for complex spatial queries.

- Projected end date: September 1, 2007

- Related topic USGS Fact Sheet 2006-3147: http://pubs.usgs. gov/fs/2006/3147/

Geodatabase of Geologic and Hydrogeologic Information for the Brazos River Alluvium, Bosque to Fort Bend County, Texas

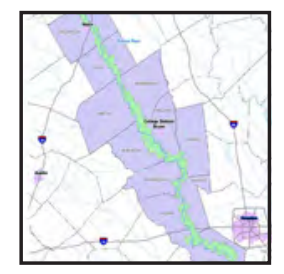

The USGS, in cooperation with the Texas Water Development Board (TWDB), developed a comprehensive geodatabase of temporal and spatial information associated with the geology and hydrogeology of the Brazos River alluvium in 13 counties in the Brazos River watershed. This compilation documents and provides a 
single consolidated geodatabase of the Brazos River alluvium geologic and hydrogeologic data that follows the TWDB Groundwater Availability Model (GAM) Source Data Geodatabase format. This includes but is not limited to, top and base elevation point locations of alluvium data and historical hydrogeologic data such as hydraulic conductivity, specific capacity, and transmissivity.

- Projected end date: September 1, 2007

- 2007 USGS Open-File Report 2007-1031

\section{Extreme Bed-Material Mobility, Edwards Plateau: Year 4}

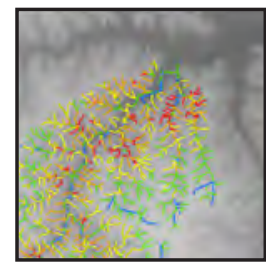

The USGS, in cooperation with the Texas Department of Transportation (TxDOT), is generating and analyzing fluvial geomorphic data to understand frequency of bed-material entrainment in stream reaches in the Edwards Plateau, associated with extensive maintenance issues for the TxDOT at bridges and lowwater crossings. Digital elevation models (DEMs) and digital orthophoto quarter-quadrangles (DOQQs) are analyzed in GIS to produce a variety of geomorphic metrics including drainage area, channel slopes, and channel widths. Trend analysis investigates linkages between road crossings with considerable problems and geomorphic metrics.

- Projected end date: September 1, 2007

- 2005 USGS Open-File Report 2005-1234: http://pubs.usgs. gov/of/2005/1234/

Watershed and Land-Use/Land-Cover Geodatabase for NAWOA Lake/Reservoir Coring Project

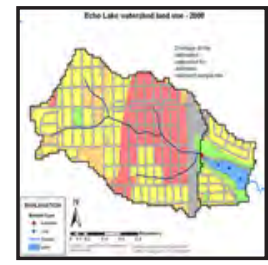

The USGS National Water Quality Assessment (NAWQA) program coordinates a study that examines sediment cores from selected lakes and reservoirs across the United States. Laboratory analysis of sediment cores provides information to determine relative constituent loadings and concentrations for each water body since the 1950s. GIS has been used for this project to determine drainage areas and land-use/land-cover change in watersheds over time.

- 2003 USGS Water-Resources Investigations Report 03-4169: http://pubs.usgs.gov/wri/wri034169/

- 2004 USGS Scientific Investigations Report 2004-5184: http://pubs.usgs.gov/sir/2004/5184/

- 2006 USGS Data Series 166: http://pubs.usgs.gov/ $d s / 2006 / 166 /$
Water-Level Altitudes 2007 and Water-Level Changes in the Chicot, Evangeline, and Jasper Aquifers and Compaction 19732006 in the Chicot and Evangeline Aquifers, Houston-Galveston Region, Texas

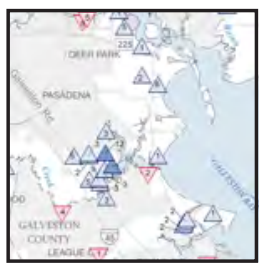

The USGS, in cooperation with the Harris-Galveston Subsidence District, the City of Houston, the Fort Bend Subsidence District, and the Lone Star Groundwater Conservation District, prepares an annual series of reports that depicts water-level altitudes and water-level changes in the Chicot, Evangeline, and Jasper aquifers, and compaction in the Chicot and Evangeline aquifers in the Houston-Galveston region. Beginning in 2007 a multi-user geodatabase was designed that allows the USGS to effectively input, generate, and manage data from both the Houston and Austin offices. The use of map templates streamlines the annual map series production.

- Project Web site: http://tx.usgs.gov/subsidence/

\section{Colonia Health Infrastructure Platting Status (CHIPS) Tool}

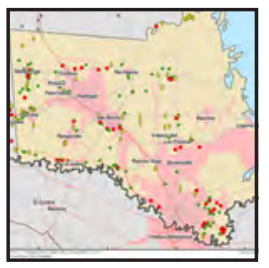

In cooperation with the Office of the Texas Secretary of State (SOS) and the Office of the Attorney General of Texas, the USGS created CHIPS to monitor the progress of projects oriented towards the improvement of colonia infrastructure. CHIPS is a relational database housed in Microsoft Access that includes a customizable report generator. Although CHIPS was developed for the SOS in response to Senate Bill 827 (SB827), this project is part of a larger project involving the USGS, the U.S. Department of Housing and Urban Development, and Mexico's Instituto Nacional de Estadística Geografía e Informática.

- 2004 USGS Fact Sheet 2004-3070: http://erg.usgs.gov/isb/ pubs/factsheets/fs307004.html

- SOS Final Report: http://www.sos.state.tx.us/border/forms/ sb827_111706.pdf

- 2007 USGS Open-File Report 2007-1230: http://pubs.usgs. gov/of/2007/1230/

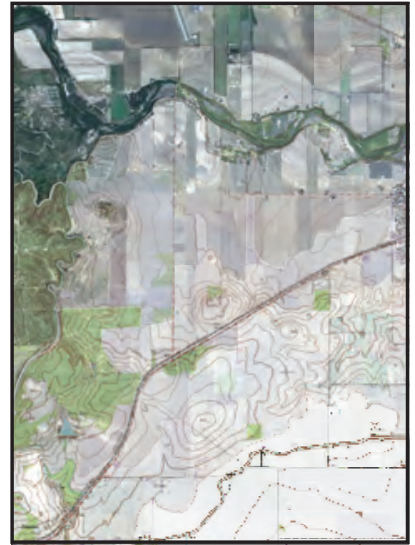

Information regarding water resources in Texas is available at http://tx.usgs.gov/ 